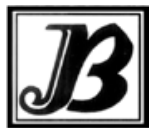

J. Bio-Sci. 25: 17-26, 2017

ISSN 1023-8654

http://www.banglajol.info/index.php/JBS/index

\title{
CROSS-SECTIONAL ANATOMY OF LEAF BLADE AND LEAF SHEATH OF COGON GRASS (IMPERATA CYLINDRICA L.)
}

\author{
SN Sima ${ }^{1 *}$, AK Roy ${ }^{2}$, MT Akther ${ }^{1}$ and $N$ Joarder $^{1}$ \\ ${ }^{1}$ Department of Botany, University of Rajshahi, Bangladesh \\ ${ }^{2}$ Department of Genetic Engineering and Biotechnology, University of Rajshahi, Bangladesh
}

\begin{abstract}
Histology of leaf blade and sheath of cogon grass (Imperata cylindrica L.) Beauv., indicated typical $\mathrm{C}_{4}$ Kranz anatomy. Cells of adaxial epidermis were smaller and bulliform cells were present on the adaxial epidermis. The shape of bulliform cells was bulbous; 3-7 cells were present in a group and 3-5 folds larger than epidermal cells. Three types of vascular bundles in respect of size and structure were extra large, large and small and they were part of leaf blade histology. These three sizes of vascular bundles were arranged in successive manner from midrib to leaf margin. Leaf sheath bundles were of two types: large and small. Extra large bundles were flanked by five small and four large bundles but small bundles were alternate found to be with large typed bundles. Extra large bundles were of typical monocotyledonous type but the large type had reduced xylem elements and the small typed was found to be transformed into treachery elements. Small be bundles occupied half the thickness of the flat portion of leaf blade topped by large bulliform cells of the adaxial epidermis. Extra large and large bundle had been extended to upper and lower epidermis. Kranz mesophyll completely encircled the bundle sheath and radiated out into ground tissue. Midrib was projected in abaxial direction and had a central vascular bundle with large and small bundles on either side of it along the abaxial regions. The midrib vascular bundle was devoid of chlorenchymatous bundle sheath and was of non-Kranz type. Continuous sub-epidermal sclerenchyma girders were noted as adaxial hypodermis. Anatomical traits exhibited an important adaptive defense against draught and saline stress of the plant. Quantitative measurement of various anatomical traits indicated strong variations among them.
\end{abstract}

Key words: Cogon grass, epidermis, kranz anatomy, leaf blade, vascular bundles

\section{Introduction}

Imperata cylindrical L. commonly known as Cogon grass (Bengali - 'Sone'), an aggressive, rhizomatous and weedy grass, is a troublesome weed throughout the tropical and subtropical region of the world. In Bangladesh it is conserved and even cultivated in arid lands for its use as domestic dust sweepers and roofing of thatched cottage. It is a good sand binder and possesses great adaptability to various habitats like saline costal belt to drought hit areas of Bangladesh. It has several ecotypes (Chang and Chou 1997) of which sun and shade ecotypes are most prevalence in Bangladesh. It has been listed as one of the seven worst weeds of the world (Chang and Chou 1997). Cogon grasses grow in high temperature region and belong to the family Gramineae. It is assumed to have Kranz type leaf anatomy similar to those of $C_{4}$ plants.

A large number of graminaceous species possess Kranz anatomy, where leaf vascular bundles have two concentric and adjacent sheaths, an inner mestome sheath of small, very thick walled, chlorenchyma lacking

*Author for correspondence: sima_bot2006@yahoo.com 
cells; and an outer parenchyma sheath of thick or thin-walled cells, with few to numerous chloroplasts and of cell sizes from average to quite large. Parenchymatous bundle sheath in most cases is associated with mesophyll cells but there are numerous exceptions of the general description (Brown 1975).

Many $\mathrm{C}_{4}$ monocots contain suberin in the wall of the kranz cells, a feature that is absent from the eudicots (Hattersley and Browing 1981, Edwards and Vozensenskaya 2011, Mertz and Brutnell 2014). Suberin slows diffusive efflux, thus event in the formation of the modern biosphere (Edwards et al. 2010, Christin et al. 2013, Slewinski 2013).

Biologists are now in a much better position to resolve the kranz enigma as new developmental models and genomic tools to facilitate the linkage of traits with the underlying genetic control (Covshoff et al. 2012 and 2014, Williams et al. 2013, Fouracre et al. 2014). The present study was under taken to identify Kranz system of anatomy of leaf-sheath, leaf-blade and leaf-midrib of Imperata cylindrica L.

\section{Materials and Methods}

Imperata cylindrical L. naturally grown in the Botanical Garden, University of Rajshahi was collected from five different regions of the gardens. Ten healthy full grown plants from each region were selected at random and full grown leaves with leaf sheath were sampled from each plant. Plant samples were collected from the middle of the leaf blade and leaf sheaths for anatomical study. Free hand transverse sections were cut for leaf sheath and leaf blade; thin sections were selected and stained with double stain technique (Johanson 1940). Cross sectional anatomy were examined through a research microscope fitted with digital camera and connected with Macintosh computer.

Gross anatomy were studied by taking microphotographs and quantitative measurements of various tissue, cells etc. were made through image analysis using Motic j1.0 software. Collected data on the attributes analyzed through range, mean with standard deviation and tested between plants within sample area.

\section{Results and Discussion}

Transverse sections through leaf blade are shown in Figs 1 and 2. The blade exhibited Kranz anatomy characteristic of $\mathrm{C}_{4}$ grasses (Esau 1977, Dangler et al. 1994) with mesophyll radially arranged around chlorenchymatous bundle sheath. The layers of Kranz mesophyll radially encircling successive bundles were separated from one another by a layer of non-Kranz cells, or colourless cell, containing few chloroplasts (Fig. 2).

In some observations the colourless cells resembles the bulliform cells of the adaxial epidermis and often are in contact with them. In most of the observations, the maximum lateral cells counted were two i.e. there are two Kranz mesophyll cells between chlorenchymatous bundle sheaths (Figs 3 and 4). The mesophyll cells were much branched and loosely arranged, having numerous intercellular air spaces among them.

\section{Anatomy of the mid rib and leaf blade}

As seen in any given transverse section, three types of longitudinal vascular bundles have been recognized: extra large, large and small. Three types of vascular bundles in leaf blade of grasses have been reported by Artschwager (1925) and after a long time by Ellis (1976). Commonly small bundles are alternated with large bundles. Extra large bundles (Fig. 2) are flanked by five small and four large bundles. In sugarcane, large bundles were found to be flanked by small ones or an intermediate one (Colbert and Evert 1982). Almost all of the longitudinal bundles of the blade were associated with longitudinal plates or strands of hypodermal sclerenchyma (Figs 1-3). In general the sclerenchyma was found to be strongly developed in the large vascular bundles. Moreover, the leaf margins had sclerenchyma at all levels of the blade. 

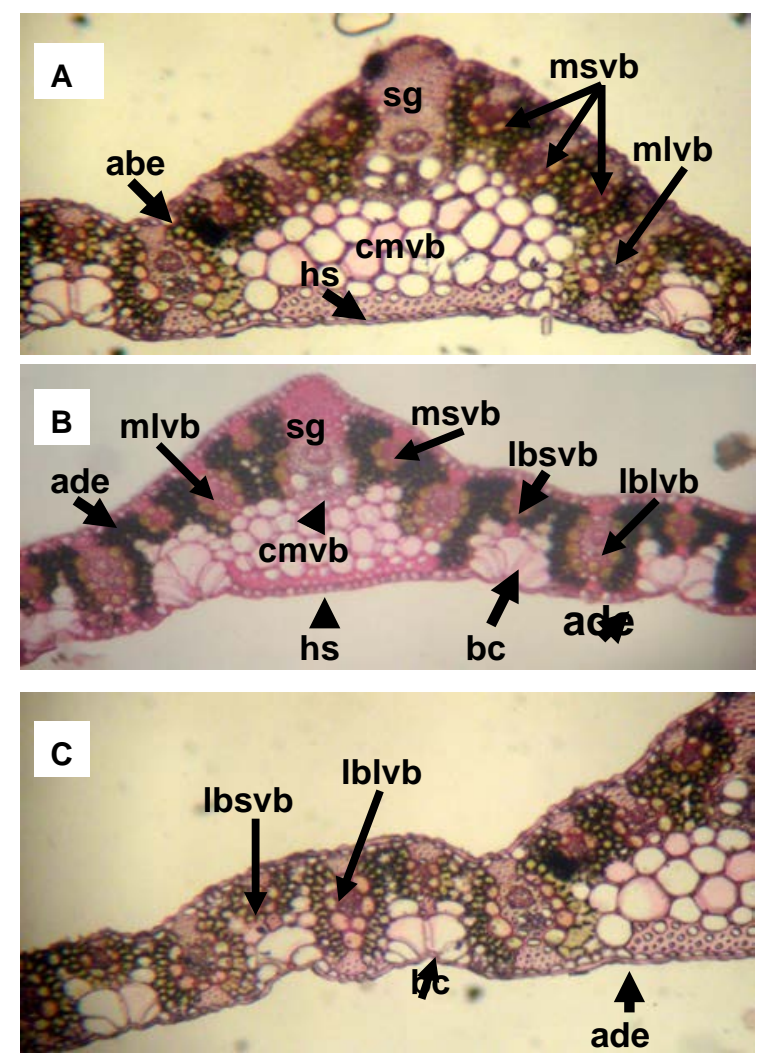

Fig. 1. Transverse section of leaf blade with midrib of cogon grass (A, B and $C)$ : abe = abaxial epidermis; $\mathrm{msvb}=$ midrib small vascular bundles; $\mathrm{cmvb}=$ central vascular bundle; $\mathrm{hs}=$ hypodermal sclerenchyma; mlvb = midrib large vascular bundle; $b c=$ bulliform cell; lbsvb = leaf blade small vascular bundle; $\mid \mathrm{blvb}=$ leaf blade large vascular bundle; ade = adaxial epidermis $\mathrm{sg}=$ sclerenchyma girder.

The midrib shape was more or less conical by projected in abaxial direction. It consisted of a central large vascular bundle along with few small and medium bundles on either side touching abaxial epidermis (Fig. 1). In the midribs a continuous sub epidermal layer of sclerenchyma commonly formed beneath the adaxial epidermis. The central region of the midrib has colourless thin walled cells usually larger in size (Fig. 1) similar to those reported in sugarcane (Colbert and Evert 1982). The central vascular bundle of the midrib as measured was $2144.16 \mu \mathrm{m}^{2}$ (ranged 1642-2471 $\mu \mathrm{m}^{2}$ ). Hameed and Ashraf (2009) reported larger size vascular bundles in Cogon grass. 


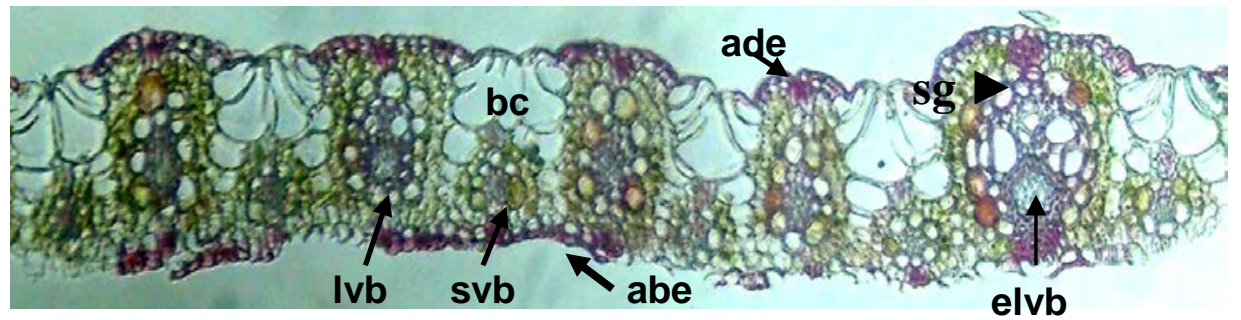

Fig. 2. Transverse section of leaf blade excluding midrib. ade = adaxial vascular bundle; $b c=$ bulliform cell; $s g=$ sclerenchyma girder; Ivb = large vascular bundle; elvb = extra large vascular bundle; $a b e=$ abaxial epidermis; $s v b=$ small vascular bundle.

The mean inter-veinial distance as calculated from middle of one bundle to middle of another bundle was $38.64 \pm 1.64 \mu \mathrm{m}$ in the blade and that in midrib was $27.66 \pm 3.14 \mu \mathrm{m}$. Interveinal distance is shorter in $\mathrm{C}_{4}$ grasses (Dangler et al.1994). In sugarcane it is variable depending on the genotypes (Elahi and Ashraf 2001). Midrib thickness as measured was $429.66 \pm 41.32 \mu \mathrm{m}$ (range 287- $494 \mu \mathrm{m}$ ) and that in leaf blade was $196.47 \pm 14.33 \mu \mathrm{m}$ (ranged $124-266 \mu \mathrm{m}$ ). Adaxial epidermis thickness of leaf sheath and midrib were $6.46 \pm 0.84 \mu \mathrm{m}$ and $7.86 \pm 0.72 \mu \mathrm{m}$ respectively. The abaxial epidermis thickness was measured $11.67 \pm$ $1.04 \mu \mathrm{m}$ and $14.07 \pm 1.49 \mu \mathrm{m}$ respectively in midrib and leaf blade. Hameed and Ashraf (2009) reported a very high range of those measurements depending on ecotypes and salt range in the habitat.

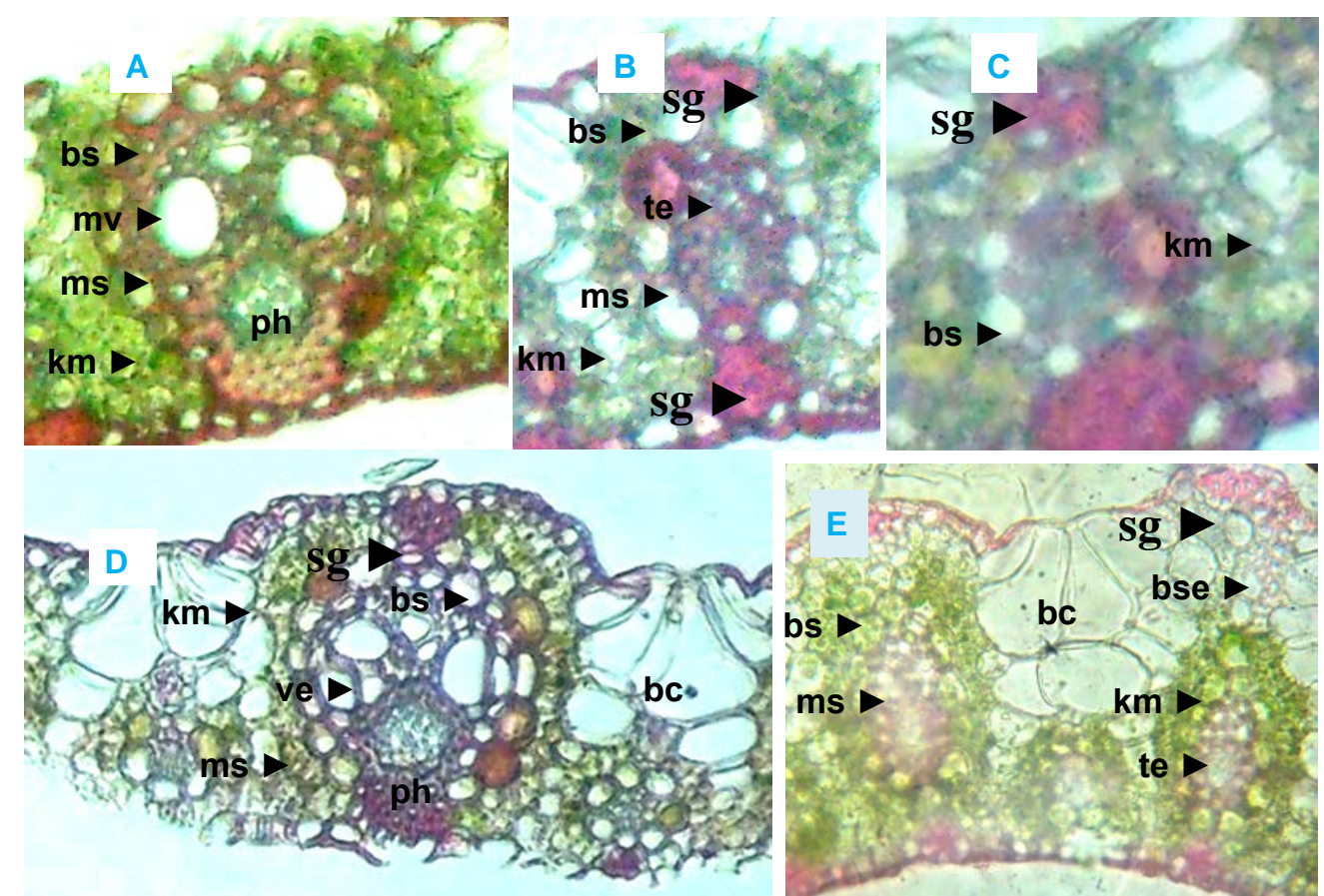

Fig. 3. Enlarged view of various vascular bundle of leaf blade. A. large bundle; B. Large VB from midrib; C. Small VB; D. Extra large VB; E. Two large bundle with a small VB. One of the large bundle developed bundle sheath extension. bs = bundle sheath; $\mathrm{mx}$ metaxylem vessel; $\mathrm{ms}=$ mestome sheath; $\mathrm{ph}=$ phloem; $\mathrm{bc}=$ bulliform cell; $\mathrm{sg}=$ sclerenchyma girder; $\mathrm{km}=$ Kranz mesophyll; te = tracheary element. 
Table 1. Anatomical characters of midrib of Cogon grass leaf (Mean \pm standard deviation and range).

\begin{tabular}{cccccccc}
\hline $\begin{array}{c}\text { Vascular } \\
\text { bundle at } \\
\text { midrib } \\
\left(\mu \mathrm{m}^{2}\right)\end{array}$ & $\begin{array}{c}\text { Interveinial } \\
\text { distance in } \\
\text { midrib }(\mu \mathrm{m})\end{array}$ & $\begin{array}{c}\text { Midrib } \\
\text { Thickness } \\
(\mu \mathrm{m})\end{array}$ & $\begin{array}{c}\text { Adaxial } \\
\text { epidermis } \\
\text { thickness of } \\
\text { midrib }(\mu \mathrm{m})\end{array}$ & $\begin{array}{c}\text { Abaxial } \\
\text { epidermis } \\
\text { thickness } \\
(\mu \mathrm{m})\end{array}$ & $\begin{array}{c}\text { Buliform } \\
\text { complex area } \\
\text { in midrib } \\
\left(\mu \mathrm{m}^{2}\right)\end{array}$ & $\begin{array}{c}\text { Midrib } \\
\text { vascular } \\
\text { bundle area } \\
\text { small }\left(\mu \mathrm{m}^{2}\right)\end{array}$ & $\begin{array}{c}\text { Midrib vascular } \\
\text { bundle area } \\
\text { large }\left(\mu \mathrm{m}^{2}\right)\end{array}$ \\
2144.16 & $27.66 \pm 2.14$ & $429.66 \pm 41.32$ & $7.86 \pm 0.72$ & $11.67 \pm 1.04$ & $2896.09 \pm 141.22$ & $1887.33 \pm 239.75$ & $2971.17 \pm 266.44$ \\
$1642-2471$ & $25.30-30.45$ & $287.0-494.0$ & $7.75-8.20$ & $10.85-12.44$ & $2144.0-3864.0$ & $1667.8-2045.2$ & $2590.4-3127.4$ \\
\hline
\end{tabular}

Table 2. Anatomical characters of midrib of Cogon grass leaf (Mean \pm standard deviation and range).

\begin{tabular}{|c|c|c|c|c|c|c|}
\hline $\begin{array}{l}\text { Phloem area } \\
\text { of extra } \\
\text { large } \\
\text { vascular } \\
\text { bundle }\left(\mu \mathrm{m}^{2}\right)\end{array}$ & $\begin{array}{c}\text { Phloem area } \\
\text { of large } \\
\text { vascular } \\
\text { bundle }\left(\mu \mathrm{m}^{2}\right)\end{array}$ & $\begin{array}{c}\text { Phloem area } \\
\text { of small } \\
\text { vascular } \\
\text { bundles } \\
\left(\mu \mathrm{m}^{2}\right)\end{array}$ & $\begin{array}{l}\text { Xylem area of } \\
\text { large vascular } \\
\text { bundles }\left(\mu \mathrm{m}^{2}\right)\end{array}$ & $\begin{array}{l}\text { Xylem area of } \\
\text { small vascular } \\
\text { bundles }\left(\mu \mathrm{m}^{2}\right)\end{array}$ & $\begin{array}{l}\text { Percentage of } \\
\text { phloem and } \\
\text { xylem area of } \\
\text { large vascular } \\
\text { bundle }\end{array}$ & $\begin{array}{l}\text { Percentage of } \\
\text { phloem and } \\
\text { xylem area of } \\
\text { small vascular } \\
\text { bundle }\end{array}$ \\
\hline $924.64 \pm 76.124$ & $624.87 \pm 78.32$ & $447.44 \pm 47.24$ & $1027.45 \pm 239.16$ & $469.77 \pm 67.12$ & $19.86 \%$ and $32.65 \%$ & 21.89 and $22.64 \%$ \\
\hline $885.6-1022.2$ & $547.4-698.0$ & $397.5-521.7$ & $877.0-1289.3$ & $402.9-521.0$ & - & - \\
\hline
\end{tabular}

Table 3. Anatomical characters of leaf blade of Cogon Grass leaf (Mean \pm standard deviation and range).

\begin{tabular}{lccccc}
\hline $\begin{array}{l}\text { Interveinial } \\
\text { distance in leaf } \\
\text { blade }(\mu \mathrm{m})\end{array}$ & $\begin{array}{c}\text { Leaf blade } \\
\text { thickness } \\
(\mu \mathrm{m})\end{array}$ & $\begin{array}{c}\text { Abaxial epidermis } \\
\text { thickness }(\mu \mathrm{m})\end{array}$ & $\begin{array}{c}\text { Leaf blade vascular } \\
\text { bundle area extra } \\
\text { large }\left(\mu \mathrm{m}^{2}\right)\end{array}$ & $\begin{array}{c}\text { Leaf blade vascular } \\
\text { bundle area large } \\
\left(\mu \mathrm{m}^{2}\right)\end{array}$ & $\begin{array}{c}\text { Leaf blade vascular } \\
\text { bundle area small } \\
\left(\mu \mathrm{m}^{2}\right)\end{array}$ \\
\hline $38.64 \pm 1.64$ & $196.47 \pm 14.33$ & $14.07 \pm 1.49$ & $5412.66 \pm 279.14$ & $3146.77 \pm 271.44$ & $2044.66 \pm 234.49$ \\
$36.8-40.2$ & $124.0-266.0$ & $12.5-16.7$ & $5232.5-5654.8$ & $2970.4-323.0$ & $1477-2697$ \\
\hline
\end{tabular}

Extra large and a few large bundles were characterized by the presence of a large metaxylem vessel on either side of the protoxylem or protoxylem lacuna (Figs $3 \mathrm{~A}$ and D). Protoxylem was also present but in mature bundles it was usually obliterated. Protophloem not detected but active metaphloem in sieve tube and companion cells was the only conducting phloem as reported in sugarcane (Colbert and Evert 1982). Except the central midrib bundle, the large blade bundles were more or less completely surrounded by a chlorenchymatous bundle sheath, which was often interrupted on the adaxial and/or abaxial surfaces by girders of hypodermal sclerenchyma (Figs 1 and 2). An inner mestome sheath with thickened walls was always present around the phloem, and may be present around all or partly of the xylem (Fig. 3). In the midrib, the central vascular bundle lack a distinctive chlorenchymatous bundle sheath, and were associated on the abaxial surfaces with well developed sclerenchyma girders, which merged with sclerified cells subtending the phloem (Fig. 1).

The bundle sheath cells of the midrib central bundle had transformed into thick walled cells and commonly only those cells bordering the phloem had chloroplast. It is those bundle sheath cells that were in contact with Kranz mesophyll cells. The large bundles, except in midrib region, essentially were found to be extended from epidermis to epidermis (Figs 1 and 2).

Large bundles of the leaf blade (except extra large one) together with their bundle sheaths essentially were extended from upper and lower epidermis. Unlike extra large bundles, large blade bundles were lack larger 
metaxylem vessels and protoxylem; such bundles were consisted of sieve tube and companion cells. Large bundles were almost completely surrounded by a chlorenchymatous bundle sheath and were associated with both adaxially and abaxially by hypodermal sclerenchyma (Figs 1-3). The chlorenchymatous bundle sheath cells were always bordered by Kranz mesophyll (Figs 1- 3). An inner mestome sheath borders the phloem, although it may not be complete. Bundle morphology of large type in Cogon grass was similar to those of intermediate bundles of sugarcane (Colbert and Evert 1982, Elahi and Ashraf 2001).

Unlike large bundles of the blade, small bundles occupied only half the thickness of the flat portions of the blade, being close to the abaxial epidermis and topped by large bulliform cells of the adaxial epidermis (Fig. 1 and 2). The small bundles were consisted of entirely metaxylem and metaphloem (Figs 2 and 3). Small bundles were completely encircled by a chlorenchymatous bundle sheath and merged with the girder of hypodermal sclerenchyma of abaxial epidermis. Moreover the inner sheath of thick walled cells was not visible with light microscope. All the chlorenchymatous bundle sheath cells of the small blade bundles were in direct contact with the Kranz mesophyll. Lack of mestome sheath of small bundles had been reported in grasses (Carolin et al. 1973, Crookston and Moss 1973, Brown 1975) and in sugarcane (Colbert and Evert 1982).

Bulliform complex area ranged from $2144-3864 \mu \mathrm{m}^{2}$ in different leaves with a mean value of $2896.09 \pm$ $141.22 \mu \mathrm{m}^{2}$. Compared to bulliform cell area, small blade bundle area ranged from $1477-2697 \mu \mathrm{m}^{2}$ (mean $=2044.66 \pm 234.49 \mu \mathrm{m}^{2}$ ) in different leaves studied. Bulliform cells play an important role in leaf rolling to avoid water loss during drought stress (Abernethy et al. 1998, Balsamo et al. 2006, Alverez et al. 2008). The presence of greatly enlarged bulliform cells is a significant adaptation against water loss under drought condition. Extensive leaf rolling was observed during summer months. Hameed and Ashraf (2009) in Cogon grass and Arton (1986) in some species of Axonopus observed the similar phenomenon.

Leaf blade vascular areas were measured and it was $5412.66 \pm 279.14 \mu \mathrm{m}^{2}, 3146.77 \pm 271.44 \mu \mathrm{m}^{2}$ and $2044.66 \pm 234.49 \mu \mathrm{m}^{2}$ for extra large, large and small bundles respectively. Midrib bundles (except central vascular bundles) as measured were $1887.33 \pm 239.75 \mu \mathrm{m}^{2}$ and $2971.17 \pm 266.44 \mu \mathrm{m}^{2}$, respectively for small and large bundles. Hameed and Ashraf (2009) reported very high estimates of vascular bundle area of Cogon grass.

Phloem area of the extra large vascular bundle was $924.66 \pm 76.12 \mu \mathrm{m}^{2}$. The xylem area was $2416.33 \pm$ $149.77 \mu \mathrm{m}^{2}$. Phloem and xylem area were consisted of $17.08 \%$ and $44.64 \%$ of the vascular bundle area, respectively. Smaller phloem size compared to xylem area has been reported in Cogon gras by (Hameed and Ashraf 2009). High standard error attached with the mean of phloem and xylem area is indication of high range of variation existed in different sample area. Hameed and Ashraf (2009) noted high variation in vascular bundle traits in ecotypes of Cogon grass grown in different range of salt level. Phloem area of large and small bundles were $624.87 \pm 78.32 \mu \mathrm{m}^{2}$ and $447.44 \pm 47.24 \mu \mathrm{m}^{2}$, and these for xylem were $1027.45 \pm$ $239.16 \mu \mathrm{m}^{2}$ and $469.77 \pm 67.12 \mu \mathrm{m}^{2}$, respectively. Percentage of phloem and xylem area of large vascular bundle over large vascular bundle area was $19.86 \%$ and $32.65 \%$; and those for small bundles were $21.89 \%$ and $22.64 \%$, respectively.

\section{Anatomy of sheath}

Transverse sections of leaf sheath are shown in Figs 4 and 5. Leaf sheath thickness was greater in the midpoint and tapered towards the margin. The midpoint was round in contrast to midrib (Fig. 4). Leaf sheath also exhibited Kranz anatomy as in leaf blade. Sugarcane leaf sheath do not have Kranz anatomy (Colbert and Evert 1982). It was comprised of a large vascular bundle flanked by 2-3 small bundles of Kranz type. Central bundle have two large metaxylem vessels and protoxylem (Figs 5 and 6 ). 

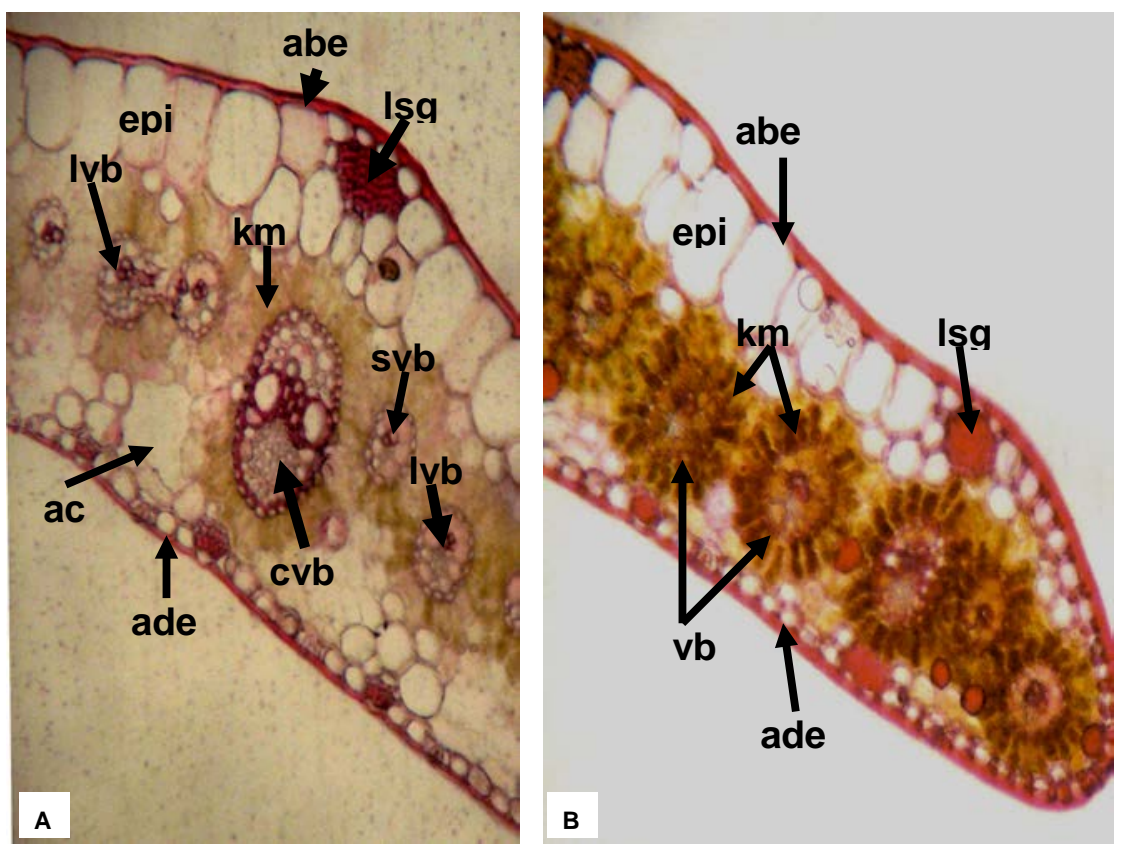

Fig. 4. Transverse section through leaf sheath. A. section through middle of mid region equivalent of midrib of blade, B. Section through margin of sheath. abe = abaxial epidermis; lag = large sclerenchyma girder; epi = epidermis; $\mathrm{km}=$ kranz mesophyll; Ivb = large vascular bundle; $\mathrm{cvb}=$ central vascular bundle; $\mathrm{ac}=$ air cavity; ade = adaxial epidermis; $v b=$ vascular bundle in the margin.

Phloem was large and well developed. As seen in transverse sections, the pattern of longitudinal bundles in the sheath was more regular than that in blade. Beginning at the margin there were usually one or two small bundles (Fig. 4) followed by uniformly arrange fairly large bundles of equal size. The bundles in the margin were measured as $714.49 \pm 31.34 \mu \mathrm{m}^{2}$ and next to these as measured as $945.66 \pm 41.41 \mu \mathrm{m}^{2}$. The large centre bundle as measured was $1424.67 \pm 149.11 \mu \mathrm{m}^{2}$. Leaf sheath bundle area as measured in Cogon grass was very high as reported and ranged from 5919-8282 $\mu \mathrm{m}^{2}$ (Hameed and Ashraf 2009). These differences with our study could be due to ecotype differences. Central mid bundle and most bundles in the margin are associated with fairly large amounts of sclerenchyma, particularly on their abaxial surface (Fig. 4).

Adaxially a vascular bundle may or may not be contiguous to a sclerenchyma strand. Sclerenchyma thickness as measured $16.69 \pm 0.94 \mu \mathrm{m}^{2}$, which was largest in abaxial surface but it was $7.14 \pm 0.19 \mu \mathrm{m}^{2}$ in adaxial side. Ecotype and habitat influenced sclerenchyma thickness in Cogon grass (Hameed and Ashraf 2009). Leaf sheath bundles together with their bundle sheath and kranz mesophyll essentially extended from upper to lower epidermis (Fig. 5). The abaxial epidermal cells were very large, radially elongated, and each measured $343.55 \pm 34.11 \mu \mathrm{m}^{2}$. The adaxial epidermal cells were small in size and each measured as $8.19 \pm$ $0.24 \mu \mathrm{m}^{2}$. Hameed and Ashraf (2009) reported larger abaxial and smaller adaxial epidermal cell area in Cogon grass. A clear large air cavity was observed in the leaf sheath midpoint which measured $624.22 \pm$ $47.66 \mu \mathrm{m}^{2}$. Presence of aerenchyma in Cogon grass has been reported by Hameed and Ashraf (2009). 
Table 4. Anatomical characters of leaf sheath of Cogon Grass (Mean \pm standard deviation and range).

\begin{tabular}{ccccccccc}
\hline $\begin{array}{c}\text { Leaf sheath in } \\
\text { the margin } \\
\text { small bundle1 } \\
\left(\mu \mathrm{m}^{2}\right.\end{array}$ & $\begin{array}{c}\text { Leaf sheath in } \\
\text { the margin } \\
\text { small bundle2 } \\
\left(\mu \mathrm{m}^{2}\right)\end{array}$ & $\begin{array}{c}\text { Leaf } \\
\text { sheath } \\
\text { centre } \\
\text { bundle } \\
\left(\mu \mathrm{m}^{2}\right)\end{array}$ & $\begin{array}{c}\text { Adaxial } \\
\text { epidermis } \\
\text { thickness } \\
\text { in leaf } \\
\text { sheath } \\
(\mu \mathrm{m})\end{array}$ & $\begin{array}{c}\text { Adaxially } \\
\text { vascular } \\
\text { bundle } \\
\text { sclerenchym } \\
\text { a thickness } \\
\left(\mu \mathrm{m}^{2}\right)\end{array}$ & $\begin{array}{c}\text { Abaxially } \\
\text { vascular } \\
\text { bundle } \\
\text { sclerenchym } \\
\text { a thickness } \\
\left(\mu \mathrm{m}^{2}\right)\end{array}$ & $\begin{array}{c}\text { Abaxially } \\
\text { epidermal } \\
\text { cells large } \\
\left(\mu \mathrm{m}^{2}\right)\end{array}$ & $\begin{array}{c}\text { Abaxially } \\
\text { epidermal } \\
\text { cells small } \\
\left(\mu \mathrm{m}^{2}\right)\end{array}$ & $\begin{array}{c}\text { Leaf sheath } \\
\text { mid point air } \\
\text { cavity }\left(\mu \mathrm{m}^{2}\right)\end{array}$ \\
\hline $714.49 \pm 31.34$ & $945.66 \pm 41.41$ & $1424.7 \pm 149.11$ & $6.46 \pm 0.84$ & $16.69 \pm 0.94$ & $7.14 \pm 0.19$ & $343.55 \pm 34.11$ & $8.19 \pm 0.24$ \\
$690.3-748.2$ & $902.6-980.6$ & $1332.4-1580.7$ & $5.80-7.35$ & $15.45-17.28$ & $7.05-7.22$ & $305.5-376.5$ & $7.55-8.80$ & $57.24 .22 \pm 47.66$ \\
\hline
\end{tabular}
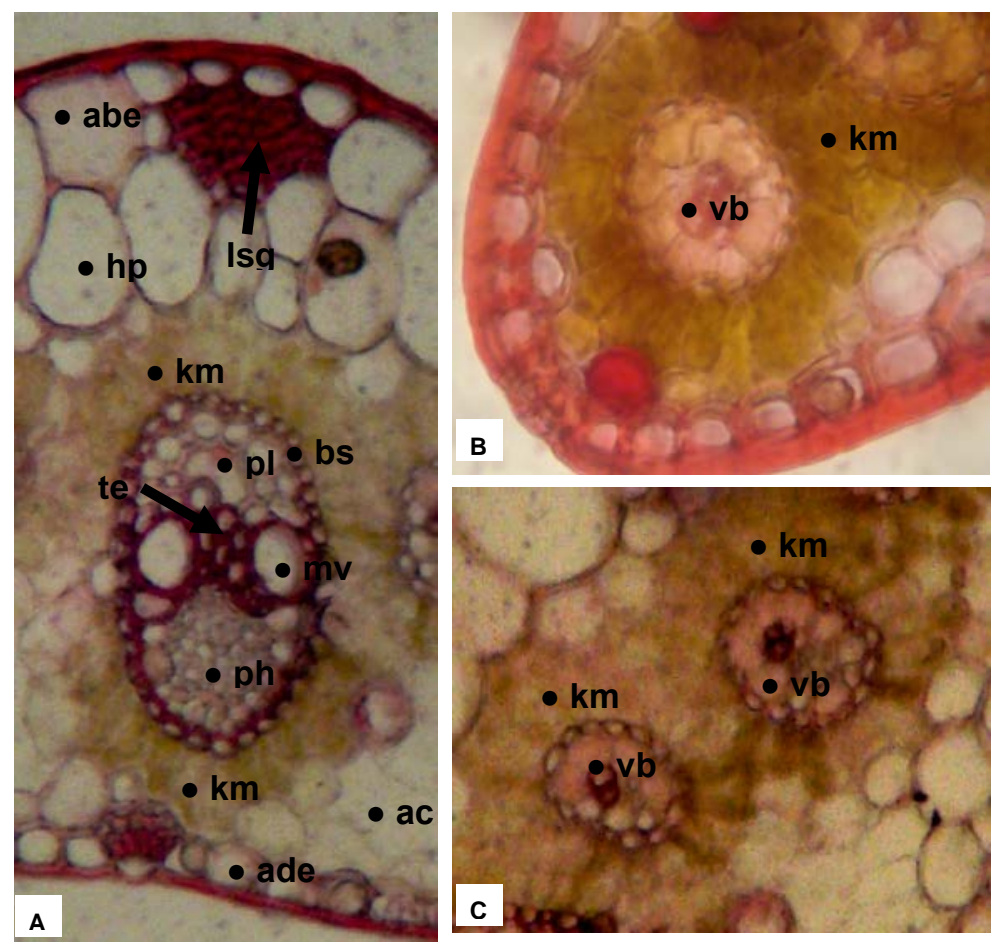

Fig. 5. Enlarged view of cross section of leaf sheath. A. Section from widest region, B. Section through margin and C. section from away margin. abe = abaxial epidermis; Isg = large sclerenchyma girder; $h p=$ hypodermis; $\mathrm{km}=$ kranz mesophyll; $\mathrm{bs}=$ bundle sheath; te = tracheary elements; $\mathrm{ph}=$ phloem; $\mathrm{ac}=$ aerenchyma; ade = adaxial epidermis; $\mathrm{mx}=$ metaxylem; $\mathrm{vb}=$ vascular bundle.

Leaf blade and leaf sheath anatomy provided good information on $\mathrm{C}_{4}$ type photosynthesis which operates in both blade and sheath. Some special adaptation like tolerant to harsh environment like well development leaf rolling system, hypodermal sclerenchyma; and aerenchyma complex were well expressed. This result could be targeted to modern molecular and genetic engineering technique for utilization of this adaptation to other crop plants. High standard error attached with various measurements indicated plant to plant variation within a selection cite is very high. It is an indication of presence of the different ecotypes in the sample area. 


\section{References}

Abernethy GA, Fountain DW and Memanus MT(1998). Observations on the leaf anatomy of Festuca novae zclandiae and biochemical responses to a water deficit. New Zealand Journal of Botany 36(1): 113-123.

Alvarex JM, Rocha JF and Machado SR (2008). Bulliform cells in Loudetiopsis chrysothnx (Nees) Conert and Tristachya leiostachya Nees (Poaceae): Brazilian Archives of Biology and Technology 51(1): 113-119.

Arton AM (1986). Contribucion al conocimient o de la anatomia foliar del genero Axonopus (Poaceae). Darwiniana 27: 157-158.

Artschwager E (1925). Anatomy of the vegetative organs of sugarcane. Journal of Agricultural Research 30: 197-221.

Balsamo RA, Willigen CV, Baner AM and Farrant J (2006). Drought tolerance of selected Eragrostis species correlations with leaf tensile properties. Annals of Botany 97(6): 985-991.

Brown WV (1975). Variation in anatomy, association and origins of Kranz tissue. American Journal of Botany 62: 395402.

Carolin R, Jacobs SWL and Vesk M (1973). The structures of the cells of the mesophyll and parenchymatous bundle sheath of the Gramineae. Botanical Journal of the Linnean Society 66 (4): 259-275.

Chang KT and Chou CH (1997). Ecotype variation of Impereta ylindrical populations in Taiwen: I. Morphological and molecular evidences. Botany Bulletin of Academia Sinica 38: 215-223.

Christin PA, Osborne CP, Chatelet DS, Columbus JT, Besnard G, Hodkinson TR, Garrison LM, Vorontsova MS and Edwards EJ (2013). Anatomical enablers and the evolution of $C_{4}$ photosynthesis. Proceeding of the National Academy of Sciences, USA 110: 1381-1386.

Colbert JT and Evert RF (1982). Leaf vasculature in sugarcane (Saccharum officinarum L.). Planta 156: 136-151.

Covshoff S, Burgess SJ, Kneřová $\mathrm{J}$ and Kümpers BM (2014). Getting the most out of natural variation in $\mathrm{C}_{4}$ photosynthesis. Photosynthesis Research 119: 157-167.

Covshoff S, Furbank RT, Leegood RC and Hibberd JM (2012). Leaf rolling allows quantification of mRNA abundance in mesophyll cells of sorghum. Journal of Experimental Botany 64: 807-813.

Crookston RK and Moss DN (1973). A variation of $C_{4}$ leaf anatomy in Arundinella hirta (Gramineae). Plant Physiology 52: 397-402.

Dangler NG, Dangler RE, Donnelly PM and Hattersley W (1994). Quantitative leaf anatomy of $C_{3}$ and $C_{4}$ grasses (Poaceae). Bundle sheath and mesophyll surface area relationships. Annals of Botany 73: 241-255.

Edwards GE and Voznesenskaya EV (2011). Kranz forms and single cell $C_{4}$ in terrestrial plants. In: Raghavendra AS, Sage RF eds. $\mathrm{C}_{4}$ photosynthesis and related $\mathrm{CO}_{2}$ concentrating mechanisms. 29-61 pp.

Edwards EJ, Osborne CP, Stromberg CAE, Smith SA and Consortium CG (2010). The origins of $\mathrm{C}_{4}$ grasslands: integrating evolutionary and ecosystem science. Science 328: 587-591.

Elahi NN and Ashraf M (2001). Study of various sized leaf vascular bundles and surrounding tissues of six sugarcane varieties. Pakistan Journal of Biological Sciences 4: 1078-1082.

Ellis RP (1976). A procedure for standardizing comparative leaf anatomy of the Poaceae. I. The leaf blade as viewed in transverse section. Bothalia 12: 65-109.

Esau K (1977). Anatomy of seed plants. 2nd ed., Wiley, New York. 
Fouracre JP, Ando S and Langdale JA (2014). Cracking the Kranz enigma with systems biology. Journal of Experimental Botany 65: 3327-3339.

Hameed M and Ashraf M (2009). Anatomical and adaptations to salinity in cogon grass [Imperata cylindrica (L.) Racusche l] from the salt range, Pakistan Plant Soil 322: 229-238.

Hattersley PW and Browning AJ (1981). Occurrence of the suberized lamella in leaves of grasses of different photosynthetic types. I. In parenchymatous bundle sheaths and PCR ("Kranz") sheaths. Protoplasma 109: 371-401.

Johanson DA (1940). Plant microtechnique. McGraw Hill, New York.

Mertz RA and Brutnell TP (2014). Bundle sheath suberization in grass leaves: multiple barriers to characterization. Journal of Experimental Botany 65: 3371-3380.

Slewinski TL (2013). Using evolution as a guide to engineer Kranz-type $C_{4}$ photosynthesis. Frontiers in Plant Science 4 : 1-13.

Williams BP, Johnston IG, Covshoff S and Hibberd JM (2013). Phenotypic landscape inference reveals multiple evolutionary paths to C4 photosynthesis. eLife 2: e00961. 